\title{
Survey of Major Pearl Millet Growing Districts of Madhya Pradesh to Find Out the Blast Severity Across the State
}

\author{
Ajay Kaurav*, R.K. Pandya, Ravi Yadav and Priyanka Singh \\ Department of Plant Pathology, College of Agriculture, Rajmata Vijyaraje Scindia Krishi Vishva \\ Vidyalaya, Gwalior, M.P., India \\ *Corresponding author
}

\author{
A B S T R A C T
}

Pearl millet [Pennisetum glaucum (L.)R.Br.] one of the common millets grown as a nutrient-rich food source for human and as a fodder crop for livestock. Among the several diseases, the blast caused by Pyricularia grisea (Cooke) Sacc. has emerged as a serious disease affecting both forage and grain production in pearl millet resulting economic

Keywords

Survey, Pyricularia grisea.

\section{Article Info}

Accepted:

26 September 2017

Available Online:

10 October 2017 loss.Survey was carried out in major pearl millet growing districts of Madhya Pradesh viz., Morena, Bhind, Gwalior, Sheopur, Shivpuri, Datia, jhabua, Alirajpur presented in Table 7 to find out the incidence of Blast during July to nov. 2015-16 and 2016-17. None of the surveyed fields were free from the blast disease in localities of blast severity. The severity of Blast during 2015-16 and 2016-17 in the surveyed localities ranged from 1 to 5.48\% and 3.6 to $13.8 \%$ respectively. Across the state among all pearl millet growing districts, in 2015-16, the maximum blast severity was observed in Tehsil Morena (5.48\%) in Morena district, followed by 5.08\% Morar (Gwalior), $4.92 \%$ in Lahar (Bhind), $4.76 \%$ Seopur (Seopur), 4.24\% Vijaypur (Seopur), 4.12\% Shivpuri (Shivpuri). In 2016-17, the maximum blast severity was found $13.80 \%$ in Sabalgarh (Morena), followed by $12.92 \%$ Lahar (Bhind), 12.32\% Joura (Morena), $11.48 \%$ Ater, (Bhind), 11.28\% Morena (Morena), 11.24\% Ambha (Morena). In 2015-16 and 2016-17 none of the surveyed fields remained free from the Blast disease.

\section{Introduction}

Pearl millet [Pennisetum glaucum (L.)R.Br.] one of the common millets grown as a nutrient-rich food source for human and as a fodder crop for livestock. Among the several diseases, the blast caused by Pyricularia grisea (Cooke) Sacc. has emerged as a serious disease affecting both forage and grain production in pearl millet resulting economic loss. India is the largest producer of pearl millet in Asia, both in terms of area and production. The important pearl millet growing states in the country are Rajasthan,
Gujarat, Maharashtra, Uttar Pradesh, Tamil Nadu, Karnataka, and Madhya Pradesh. It is being grown in Madhya Pradesh as sole crop for grain and fodder purposes. In India, it is cultivated over an area of 79.52 lakh ha., with the production of 87.96 lakh tones and the productivity is $1106 \mathrm{~kg} / \mathrm{ha}$. Madhya Pradesh occupies 1.87 lakh ha. With an annual production 30.1lakh tones and productivity of $1698 \mathrm{~kg} / \mathrm{ha}$. Rajasthan ranks first with an area of 3.98 mha and annual production 38.7 million tones (Anonymous, 2014). It has a 
great potential to grow on soils that are too sandy, light-textured, Acidic, dry and too infertile for other cereals. Several diseases caused by fungi, bacteria, viruses and nematodes have been recorded (Rachie and Majmudar, 1980), out of them downy mildew, blast, ergot, smut and rust are important. Blast (Pyricularia grisea (Cooke) Sacc.) has become wide spread and destructive disease of pearl millet particularly in the crop cultivated for fodder purpose. The disease was first reported in the country from Kanpur, Utter Pradesh (Mehta et al., 1953).

\section{Materials and Methods}

The cultivator field survey was carried out in major pearl millet growing districts of Madhya Pradesh viz., Morena, Bhind, Gwalior, Sheopur, Shivpuri, Datia, jhabua, Alirajpur presented in Table 1 to find out the incidence of Blast during Kharif season 201516 and 2016-17 for such survey five villages of all the selected districts were taken. The five fields from the village were randomly selected. An area of $1 \mathrm{~m} \times 1 \mathrm{~m}$ was marked at five randomly selected spots on each farmer's field.

The numbers of diseased plants were recorded in five $1 \mathrm{M}^{2}$ quadrats in each field. Plants leaf was considered diseased area. The systematic survey will be carried out on information regarding each field were noted information as incidence; sowing time and soil colour of the field was recorded.

The representative disease samples will be collected and dried for future studies. The crop in all the field visited for survey of blast severity was grown in rainfed condition and observations were recorded at grain development stage. Blast severity was recorded using $0-100 \%$ severity area on leaves.

\section{Results and Discussion}

The data summarized in table 1 reveals that Blast severity in the surveyed locations was in the range from 1 to $5.48 \%$ in the year 2015-16 and it was 3.6 to $13.8 \%$ in the year 2016-17.

In the year 2015-16 the maximum Blast severity recorded in Morena $(5.48 \%)$ tehsil of Morena district followed by Joura (4.08\%) and Sabalgarh $(4.00 \%)$ whereas, its minimum Blast severity was found in Porsa $(3.36 \%)$ followed by Ambah (3.68) \%.

District wise the maximum Blast severity was recorded in Morena (4.12\%) followed by Gwalior (4.05\%) Bhind (3.62 \%), Sheopur (3.56\%), Shivpuri (2.079\%), Datia (2.60\%).

The maximum Blast severity in 2016-17 district wise was recorded in Morena (11.34 $\%$ ), followed by Bhind (9.99 \%), Gwalior (7.60\%), Shivpuri (6.24\%), Seopur (5.76\%) while minimum in Alirajpur (4.66\%), Jhabua $(4.74 \%)$, and Datia (4.79 \%). None of the surveyed fields were free from the blast disease in localities of blast severity. The severity of Blast during 2015-16 and 2016-17 in the surveyed localities ranged from 1 to $5.48 \%$ and 3.6 to $13.8 \%$ respectively.

During 2016-17 the range of Blast severity were recorded as 3.6 to $13.8 \%$, In Morena district the maximum Blast severity was found in Sabalgarh $(13.8 \%$ which was highest), followed by $12.32 \%$ in Joura, $11.28 \%$ in Morena, $11.24 \%$ Ambah and the minimum Blast severity was recorded in 8.08\% Porsa. In Bhind district, during 201617 the status of blast severity were recorded as $12.52 \%$ in Lahar (Which was highest in Bhind district), $11.48 \%$ in Ater, $9.6 \%$ bhind, $8.8 \%$ mehgaon, $7.5 \%$ Gohad (lowest blast severity in Bhind district). $10.16 \%$ morar (Highest blast severity in Gwalior), $8.84 \%$ in Dabra, $8.12 \%$ in purani chawni, $6.44 \%$ 
gatigaon, $4.44 \%$ Bhitarwar (lowest blast severity) were blast severity in Gwalior during 2016-17. In Sheopur during 2016-17, the maximum blast severity was found in 9.84
$\%$ (Vijaypur), followed by $5.68 \%$ (Sheopur), $4.56 \%$ (karhal), $4.40 \%$ (Baroda) and the minimum smut severity was recorded $4.32 \%$ in Baroda.

Table.1 Blast severity status in different locations of Madhya Pradesh districts during 2015-16 and 2016-17

\begin{tabular}{|c|c|c|c|c|}
\hline \multirow{2}{*}{ District } & \multirow{2}{*}{ Location } & \multicolumn{3}{|c|}{ Blast severity (\%) } \\
\hline & & 2015-16 & 2016-17 & Mean \\
\hline \multirow{5}{*}{ 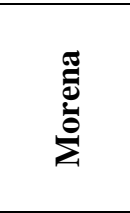 } & Morena & 5.48 & 11.28 & 7.82 \\
\hline & Ambah & 3.68 & 11.24 & 6.3 \\
\hline & Porsa & 3.36 & 8.08 & 5.1 \\
\hline & Joura & 4.08 & 12.32 & 7.88 \\
\hline & Sabalgarh & 4.0 & 13.80 & 8.24 \\
\hline \multirow{5}{*}{$\stackrel{\vec{B}}{\vec{E}}$} & Gohad & 3.2 & 7.56 & 4.46 \\
\hline & Mehgaon & 2.24 & 8.8 & 4.5 \\
\hline & Ater & 3.8 & 11.48 & 6.9 \\
\hline & Lahar & 4.92 & 12.52 & 7.98 \\
\hline & Bind & 3.96 & 9.6 & 6.1 \\
\hline \multirow{5}{*}{ 竞 } & Morar & 5.08 & 10.16 & 7.44 \\
\hline & Dabra & 4.12 & 8.84 & 3.94 \\
\hline & Purani chhawani & 4.6 & 8.12 & 4.34 \\
\hline & Gatigaon & 4.4 & 6.44 & 3.12 \\
\hline & Bhitarvar & 2.08 & 4.44 & 3.26 \\
\hline \multirow{5}{*}{ 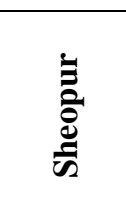 } & Sheopur & 4.76 & 5.68 & 5.22 \\
\hline & Karhal & 2.72 & 4.56 & 3.64 \\
\hline & Baroda & 3.04 & 4.40 & 3.72 \\
\hline & Baroda A & 3.08 & 4.32 & 3.7 \\
\hline & Vijaypur & 4.24 & 9.84 & 7.04 \\
\hline \multirow{5}{*}{ 吾 } & Datia & 3.52 & 5.44 & 4.48 \\
\hline & Indergarh & 2.20 & 4.28 & 3.24 \\
\hline & Bhaua pura & 2.40 & 4.48 & 3.44 \\
\hline & Seowda & 2.96 & 6.18 & 4.57 \\
\hline & Bhander & 1.96 & 3.6 & 2.78 \\
\hline \multirow{5}{*}{$\stackrel{\vec{Z}}{\mathscr{Z}}$} & Pohari & 3.36 & 8.28 & 5.82 \\
\hline & Kolaras & 2.68 & 5.64 & 4.16 \\
\hline & Pichore & 2.72 & 5.72 & 4.22 \\
\hline & Karera & 1.08 & 4.48 & 2.78 \\
\hline & Shivpuri & 4.12 & 7.12 & 5.62 \\
\hline \multirow{5}{*}{ 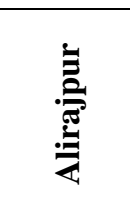 } & Alirajpur & 1.68 & 4.44 & 3.06 \\
\hline & Kattiwara & 2.0 & 4.88 & 3.44 \\
\hline & Katiwara (Andh jhiri) & 2.2 & 5.28 & 3.74 \\
\hline & Sondwa & 2.8 & 4.28 & 3.54 \\
\hline & Sondwa (Walpur) & 2.96 & 4.44 & 3.7 \\
\hline \multirow{5}{*}{ 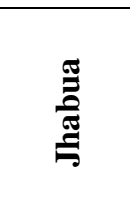 } & Ranapur (Ban) & 1.0 & 4.48 & 2.74 \\
\hline & Ranapur (Wagwa) & 1.12 & 4.56 & 2.84 \\
\hline & Ranapur (Sanod) & 1.28 & 4.72 & 3 \\
\hline & Ranapur (Partali) & 1.44 & 4.88 & 3.16 \\
\hline & Ranapur (Bhoot khedi) & 1.6 & 5.04 & 3.32 \\
\hline
\end{tabular}


Table.2 Blast severity status in Madhya Pradesh district-wise during 2015-16 and 2016-17

\begin{tabular}{|l|c|c|c|}
\hline \multirow{2}{*}{ District } & \multicolumn{3}{|c|}{ Blast severity (\%) } \\
\cline { 2 - 4 } & $\mathbf{2 0 1 5 - 1 6}$ & $\mathbf{2 0 1 6 - 1 7}$ & Mean \\
\hline Morena & 4.12 & 11.34 & 7.73 \\
\hline Bhind & 3.62 & 9.99 & 6.805 \\
\hline Gwalior & 4.05 & 7.60 & 5.825 \\
\hline Sheopur & 3.56 & 5.76 & 4.66 \\
\hline Datia & 2.6 & 4.79 & 3.695 \\
\hline Shivpuri & 2.79 & 6.24 & 4.515 \\
\hline Alirajpur & 2.33 & 4.66 & 3.495 \\
\hline Jhabua & 1.29 & 4.74 & 3.015 \\
\hline $\begin{array}{l}\text { Mean Blast severity across } \\
\text { the state Madhya Pradesh }\end{array}$ & 3.045 & & \\
\hline
\end{tabular}

Across the state among all pearl millet growing districts, in 2015-16, the maximum blast severity was observed in Tehsil Morena $(5.48 \%)$ in Morena district, followed by $5.08 \%$ Morar (Gwalior), $4.92 \%$ in Lahar (Bhind), $4.76 \%$ Seopur (Seopur), $4.24 \%$ Vijaypur (Seopur), $4.12 \% \quad$ Shivpuri (Shivpuri). In 2016-17, the maximum blast severity was found $13.80 \%$ in Sabalgarh (Morena), followed by $12.92 \%$ Lahar (Bhind), 12.32\% Joura (Morena), 11.48\% Ater, (Bhind), $11.28 \%$ Morena (Morena), 11.24\% Ambha (Morena). In 2015-16 and 2016-17 none of the surveyed fields remained free from the Blast disease (Table 2).

In the present investigation, the survey carried out during kharif 2015-16 and 2016-17 revealed that, None of the surveyed fields were free from the blast disease in localities of blast severity. The severity of Blast during 2015-16 and 2016-17 in the surveyed localities ranged from 1 to $5.48 \%$ and 3.6 to $13.8 \%$ respectively. The maximum blast severity was recorded in Morena on both the year. The two years mean data reveals that the maximum severity of Blast was recorded in Morena followed by Bhind, Gwalior, Sheopur, Shivpuri, Datia, Alirajpur while minimum was recorded in Jhabua. The higher Blast severity in Morena district might be due to some factors, such as contiguous area under monoculture, host susceptibility and early sowing i.e. from the last week of June to the first week of July. Generally High relative humidity periods and daily mean low temperature, high rainfall may be most favorable for Blast infection. Surveys conducted on 200 farmer's fields in all the pearl millet growing areas across the state, which have been grouped into low, moderate and high blast areas, with incidence levels of $1-10 \%,>10-50 \%$ and $>50-100$ (Nutsugah $e t$ al., 2008). It is an important disease in the southern United States and more recently it has emerged as a serious disease of dual purpose (grain and fodder) pearl millet hybrids in India (Lukose et al., 2007 and Anon., 2009).

None of the surveyed fields were free from the blast disease in localities of blast severity. The disease appeared as small, water soaked, grayish dots on leaves that subsequently enlarged into spindle shaped spots with grayish white center with a brown margin. Lesions often surrounded by a chlorotic halo that turned necrotic, giving the appearance of concentric rings. In severe cases, the spots coalesced to form large patches and leaves appeared blasted. 


\section{References}

Anonymous, 2009. Annual Report, All India Coordinated Pearl Millet Improvement Project (AICPMIP), Mandor, Rajasthan, India, Indian Council of Agricultural Research, New Delhi.

Anonymous, 2014. Directorate of Economics and Statistics, Department of Agriculture and Cooperation. 154.

Lukose, C.M., Kadvani, D.L. and Dangaria, C.J., 2007. Efficacy of fungicides in controlling blast disease of pearl millet.
Indian Phytopath, 60:68-71.

Mayee, C.D., and Datar, V.V., 1986. Phytopathometry Technical Bulletin-1. Marathwada Agric. Univ., Parabhani, pp.26-27.

Mehta, P.R., Singh, B., Mathur, S.C., 1953. A new leaf spot disease of bajra (Pennisetum typhoides Staph and Hubbard) caused by a species of Pyricularia. Indian Phytopath, 5:140143.

\section{How to cite this article:}

Ajay Kaurav, R.K. Pandya, Ravi Yadav and Priyanka Singh. 2017. Survey of Major Pearl Millet Growing Districts of Madhya Pradesh to Find Out the Blast Severity Across the State. Int.J.Curr.Microbiol.App.Sci. 6(10): 3084-3088. doi: https://doi.org/10.20546/ijcmas.2017.610.363 